\title{
Pharmacokinetics, safety and tolerability of L-3-v-butylphthalide tablet after single and multiple oral administrations in healthy Chinese volunteers
}

\author{
Meng Wang1, Quan-ying Zhang,"*, Wen-yan Hua', Ming Huang', Wen-jia Zhou', Kun Lou ${ }^{2}$, \\ Yue-ying Peng ${ }^{2}$
}

${ }^{1}$ Clinical Pharmacology Laboratory, The Second Affiliated Hospital of Soochow University, Suzhou, China, ${ }^{2}$ Zhongqi Pharmacy of CSPC Pharma, Shijiazhuang, China

\begin{abstract}
L-3-n-butylphthalide (L-NBP) is a naturally occurring antioxidant, which can be used for the treatment of acute ischemic stroke and vascular dementia. This study evaluated the safety, tolerability and pharmacokinetics of L-NBP tablets in healthy Chinese volunteers. This was a single-center, randomized, double-blind, placebo-controlled, single- and multiple-dose study. Subjects were assigned to receive a single dose of L-NBP tablet at either 80, 160, 320, or $480 \mathrm{mg}(\mathrm{n}=40)$, or multiple doses of $160 \mathrm{mg}$ twice daily for 7 days $(n=12)$. Plasma samples were analyzed with LC-MS/MS. Pharmacokinetic parameters of L-NBP were calculated using non-compartmental analysis with WinNonlin software. Statistical analysis was performed using SPSS software. All adverse events (AEs) were mild and of limited duration; AEs in this study occurred less frequently and more mildly than AEs listed for the DL-NBP soft capsule. No serious adverse event (SAE), death or withdrawal from the study was observed. In the single-dose study, $\mathrm{C}_{\max }$ was reached at about $1 \mathrm{~h}$, and the mean $\mathrm{t}_{1 / 2}$ was approximately $13.76 \mathrm{~h}$. Area under curve (AUC) and $\mathrm{C}_{\max }$ increased with dose escalation, but dose proportionality was not observed over the range of 160 to $480 \mathrm{mg}$. In the multiple-dose study, the steady-state was reached within 3 days with slight accumulation. In summary, the L-NBP tablet was well tolerated in healthy Chinese subjects. Slight accumulation appeared after repeated doses.
\end{abstract}

Uniterms: L-3-n-butylphthalide/tablets/safety. L-3-n-butylphthalide/tablets/tolerability. L-3- $n$ butylphthalide/tablets/pharmacokinetics. Natural antioxidant.

L-3-n-butilftalida (L-NMP) é um antioxidante natural, que pode ser utilizado para o tratamento do acidente isquêmico agudo e demência vascular. Este estudo avaliou segurança, tolerância e farmacocinética de comprimidos de L-NBP em chineses voluntários sadios. Este foi um estudo monocêntrico, randomizado, duplo cego, com controle por placebo e doses única e múltipla. Os indivíduos receberam dose única de comprimido de L-NBP de 80, 160, 320 ou $480 \mathrm{mg}(\mathrm{n}=40)$ e doses múltiplas de $160 \mathrm{mg}$ duas vezes ao dia, por sete dias $(n=12)$. Amostras de plasma foram analisadas com LC-MS/MS. Os parâmetros farmacocinéticos do L-NBP foram calculados utilizando análise não compartimental, com o programa WinNonlin. A análise estatística foi realizada utilizando-se o programa SPSS. Todos os eventos adversos (EAs) foram moderados e de duração limitada. EAs nesse estudo ocorreram menos frequentemente e mais moderadamente do que os EAs relacionados para cápsulas moles de DL-NBP. Não se observaram eventos adversos graves (EAG), morte ou abandono do estudo. Com dose única, atingiu-se o $\mathrm{C}_{\max }$ em cerca de 1 hora e o $\mathrm{t}_{1 / 2}$ médio foi de, aproximadamente, 13,76 h. A área sob a curva (ASC) e o $\mathrm{C}_{\max }$ aumentaram como aumento da dose, mas não se observou proporcionalidade na faixa acima de 160 a $480 \mathrm{mg}$. No estudo de dose múltipla, o equilíbrio foi alcançado em três dias, com pequeno acúmulo. Em resumo, o comprimido de L-NMP foi bem tolerado em indivíduos chineses saudáveis. O acúmulo pequeno apareceu após doses repetidas.

Unitermos: L-3- $n$-butilftalida/comprimidos/segurança. L-3- $n$-butilftalida/comprimidos/tolerabilidade. L-3- $n$-butilftalida/comprimidos/farmacocinética. Antioxidante natural.

*Correspondence: Quanying Zhang. Clinical Pharmacology Laboratory. The Second Affiliated Hospital of Soochow University. NO.1055 Sanxiang Road. Suzhou - 215004 - China. E-mail: enigmatz@163.com 


\section{INTRODUCTION}

L-3-n-butylphthalide (L-NBP) can be extracted from the seeds of Chinese celery (Apiumgraveolens Linn.) (Chang, Wang, 2003). L-NBP has been shown to reduce $\beta$-amylase-induced neuronal apoptosis and to improve cognitive function in Alzheimer's disease animal models (Peng et al., 2009; Peng et al., 2012; Peng et al., 2010; Peng et al., 2008; Xiang et al., 2014). Additionally, L-NBP has been demonstrated to ameliorate cognitive deficits and neuronal loss in the hippocampus of mice exposed to repetitive cerebral ischemia and reperfusion (Huai et al., 2013). L-NBP might, therefore, be used for the treatment of acute ischemic stroke and vascular dementia.

3-n-butylphthalide (NBP) is a chiral molecule that has three different stereo isomers known as L-, DL-, and D-NBP. Preclinical studies have demonstrated that L-NBP induces the strongest biological response of the NBP isomers in the vast majority of evaluations; similarly, the toxicity of L-NBP is lower than other NBP isomers. A phase I study of L-NBP sodium chloride injection was carried out at the Second Affiliated Hospital of Soochow University in 2008. L-NBP was absorbed rapidly, with $\mathrm{C}_{\max }$ reached within $1 \mathrm{~h}$; in this study, $\mathrm{C}_{\max }$ and AUC were shown to be dose-proportional over the 40-120 mg range. The steady-state conditions were achieved within 3 days after daily administration of $70 \mathrm{mg}$ L-NBP sodium chloride injection (Wang et al., 2014). DL-NBP soft capsules were approved for production in China in 2005. A phase IV clinical study showed that DL-NBP soft capsules could improve neurological deficits and promote the recovery of neurological function in acute ischemic stroke patients.

The aim of this study was to evaluate the safety, tolerability and pharmacokinetics of L-NBP tablets after single- and multiple-doses in healthy Chinese volunteers.

\section{MATERIAL AND METHODS}

\section{Drug and reagents}

Four dosages ( $80 \mathrm{mg}, 160 \mathrm{mg}, 320 \mathrm{mg}$ and $480 \mathrm{mg}$ ) of L-NBP tablets (Batch: 20080901, Specifications: $80 \mathrm{mg}$ / tablet) for single- and multiple-dose were made. L-NBP reference substance (Batch: 040708, purity: 99.7\%) was obtained from the Zhongqi Pharmacy of CSPC Pharma, Shijiazhuang, China. Diazepam reference substance (internal standard, IS, Batch: 1230-9601, purity: 100.0\%) was purchased from the National Narcotic Drug Laboratory, China. Methanol and formic acid (HPLC grade) were purchased from Tedia Company, Inc. (Fairfield, OH, USA). All other chemicals were of analytical grade.

\section{Instruments}

HPLC was performed using a 1200 Series device (Agilent Technologies, Palo Alto, CA, USA). Massspectrometric detection was performed on an API 4000 triple-quadrupole instrument (ABI-SCIEX, Ontario, Canada).

\section{Subjects}

Healthy Chinese volunteers, aged 19-45, with a body mass index (BMI) of $19-24 \mathrm{~kg} / \mathrm{m}^{2}$ and a body weight of more than $50 \mathrm{~kg}$ were eligible for inclusion in the study. Subjects were ascertained to be healthy through medical interview, physical examination, vital signs, clinical laboratory tests (e.g. hematology, blood chemistry and urinalysis), 12-lead electrocardiogram (ECG) and chest $\mathrm{X}$-ray within 2 weeks before the first dosing of the study medication. Female subjects had to be using double barrier contraception or surgically sterilized.

The study was performed in accordance with the principles of the Declaration of Helsinki and Good Clinical Practice (GCP) in China. The study protocol was reviewed and approved by the Independent Ethics Committee of the Second Affiliated Hospital of Soochow University (approval numbers: 200814 and 200904). All subjects provided written informed consent prior to entering the study.

\section{Study design}

This was a single-center, randomized, double-blind, placebo-controlled, single- and multiple-dose study. In the single-ascending-dose (SAD) study, subjects were assigned to receive a single oral administration of L-NBP tablet or placebo $(80,160,320$ or $480 \mathrm{mg})$. The study drug to placebo ratio was $3: 1$ in the 160,320 and $480 \mathrm{mg}$ groups. No placebo was used in group $80 \mathrm{mg}$ group. In the multiple- dose (MD) study, after the single-dose phase, from day 1 to day 3 , subjects were assigned to receive oral administration of $160 \mathrm{mg}$ L-NBP tablet or placebo, twice daily from day 3 to day 9 . The study drug to placebo ratio was 10:2 in this group.

Blood samples ( $4 \mathrm{~mL}$ at each time point) were taken for PK analysis in the 160, 320, and $480 \mathrm{mg}$ dosage groups at $0 \mathrm{~h}$ (pre-dose) and at $20 \mathrm{~min}, 40 \mathrm{~min}, 1,1.5,2,2.5,3,4$, $5,8,12,24,36$ and $48 \mathrm{~h}$ after dosing in the SAD study. For the pharmacokinetic assessment in the MD study, blood samples were collected at the same time points as in the SAD study, up to $48 \mathrm{~h}$ after dosing on day 1 and day 9 . Blood samples were also collected prior to dosing from 
day 6 to day 8 , to determine trough concentrations. Blood samples were collected into heparinized vacutainers and centrifuged at $3200 \times \mathrm{g}$ at $4{ }^{\circ} \mathrm{C}$ for $10 \mathrm{~min}$. All of the plasma samples were stored at $-40^{\circ} \mathrm{C}$ until analysis.

Strenuous physical activities, smoking and consumption of alcohol or caffeine-containing beverages were prohibited throughout the study.

\section{Analytical methods}

Plasma concentrations of L-NBP were determined using a validated liquid chromatography, coupled with tandem mass spectrometry (LC-MS/MS) method (Shi, Hua, Zhang, 2010). This consisted of the following steps: $200 \mu \mathrm{L}$ of plasma, $50 \mu \mathrm{L}$ of diazepam (IS) working solution, and $600 \mu \mathrm{L}$ of precipitant (methanol) were mixed in a $1.5 \mathrm{~mL}$ polypropylene tube for $1 \mathrm{~min}$ and centrifuged at $23,755 \times \mathrm{g}$ at $4{ }^{\circ} \mathrm{C}$ for $10 \mathrm{~min}$. In total, $20 \mu \mathrm{L}$ of the supernatant was injected into the LC-MS/MS (API 4000, Applied BiosystemSciex, Ontario, Canada). Each 0.1 $\mathrm{mL}$ volume of urine was centrifuged at $23,755 \times \mathrm{g}$ at $4^{\circ} \mathrm{C}$ for $10 \mathrm{~min}$, and $20 \mu \mathrm{L}$ of the supernatant was injected for analysis. The analyte was separated on an XTerra ${ }^{\circledR}$ RP18 column $(150 \mathrm{~mm} \times 4.6 \mathrm{~mm}$; id, $5 \mu \mathrm{m})$ (Waters, Ireland) with methanol-2.5 mmol/L ammonium acetate $(0.1 \%$ formic acid included) $(85: 15, \mathrm{v} / \mathrm{v})$ as the mobile phase, at a flow rate of $1 \mathrm{~mL} / \mathrm{min}$. The MS/MS was carried out in the positive ionization mode with L-NBP and IS being identified by multiple reactions monitoring (MRM) at $\mathrm{m} / \mathrm{z} 191.1 \rightarrow 145.1$ and $\mathrm{m} / \mathrm{z} 285.1 \rightarrow 193.1$, respectively. The analysis time for each run was about 3 min. This method was validated over the concentration range of $1-2000 \mathrm{ng} / \mathrm{mL}$ for all analytes in this study. The lower limit of quantification (LLOQ) was $1 \mathrm{ng} / \mathrm{mL}$. Inter- and intra-batch precision were less than $15 \%$ and the accuracy was within $85-115 \%$. A matrix-effect test indicated that the determination was not affected by the matrix. In addition, L-NBP in plasma was demonstrated to be stable under various storage conditions (e.g. $-40^{\circ} \mathrm{C}$ for at least 49 days; room temperature for $6 \mathrm{~h} ; 3$ freeze-thaw cycles; automatic sampler for $6 \mathrm{~h}$ ). Low-, medium-, and high-quality control samples $(2,12,120,1600 \mathrm{ng} / \mathrm{mL})$ were analyzed with the study samples to ensure the quality of analysis.

\section{Pharmacokinetic assessment and statistical analysis}

Pharmacokinetic analysis was performed with WinNonlin software (Version 6.3, Pharsight Corporation, Mountain View, CA, USA), utilizing non-compartmental analysis. The maximum plasma concentration $\left(\mathrm{C}_{\max }\right)$ and time to $\mathrm{C}_{\max }\left(\mathrm{t}_{\max }\right)$ were directly obtained from the concentration-time curves. The terminal-phase elimination half-life $\left(t_{1 / 2}\right)$ was calculated as $0.693 / \lambda_{z}$, where $\lambda_{z}$ was the slope of the apparent elimination phase of the natural logarithmic (ln) transformation of the plasma concentration-time curve, which was estimated using liner regression. The area under the plasma concentration-time curve from time zero to $\mathrm{t}\left(\mathrm{AUC}_{0-t}\right)$, in which $\mathrm{t}$ is the time of last measurable sample, was calculated according to the linear trapezoidal rule. The AUC from time zero to infinity $\left(\mathrm{AUC}_{0-\infty}\right)$ was estimated as $\mathrm{AUC}_{0-\mathrm{t}}+\mathrm{C}_{\mathrm{t}} / \lambda_{\mathrm{z}}$, in which $\mathrm{C}_{t}$ was the plasma concentration of the last measurable sample. Apparent total clearance $(\mathrm{Cl} / \mathrm{F})$ was calculated as Dose/AUC ${ }_{0-\infty}$ or Dose/AUC ${ }_{\text {ss, }}$ and apparent total volume of distribution $\left(\mathrm{V}_{z} / \mathrm{F}\right)$ was calculated as $\mathrm{CL} / \boldsymbol{\lambda}_{\mathrm{z}}$. Attainment of steady state by day 9 was evaluated by regressing the natural logarithmic (ln) transformation of trough concentrations on days $6,7,8$, and 9 over time. Steady-state was reached if the slope was not statistically different from zero. The steady-state AUCs $\left(\mathrm{AUC}_{\mathrm{ss}}\right)$ over the dosing interval $(\tau=12 \mathrm{~h})$ and $\mathrm{C}_{\mathrm{avg}}\left(\mathrm{AUC}_{\mathrm{ss}} / \mathrm{s}\right)$ were calculated. The degree of fluctuation (DF) was calculated as $\left(\mathrm{C}_{\max }-\mathrm{C}_{\min }\right) / \mathrm{C}_{\mathrm{avg}}$. Accumulation ratios were defined as the steady-state $\mathrm{AUC}_{0-\tau}$ to the single-dose $\mathrm{AUC}_{0-\tau}$ ratio or the steady state $\mathrm{C}_{\max }$ to the single-dose $\mathrm{C}_{\max }$ ratio, namely, $\mathrm{R}_{\mathrm{AUC}}=$ $\mathrm{AUC}_{0-\tau}$ (steady state)/AUC $\mathrm{AU}_{0-\tau}$ (single-dose) $(\tau=12 \mathrm{~h})$ and $\mathrm{R}_{\mathrm{Cmax}}=\mathrm{C}_{\max }$ (steady state) $/ \mathrm{C}_{\max }$ (single-dose), respectively. Statistical analysis was performed using SPSS software (version 17.0, SPSS, Inc, Chicago, IL, USA). Prior to the analysis, dose-dependent parameters $\left(\mathrm{C}_{\max }\right.$ and AUC) were determined using natural logarithms of individual values. For the exploration of dose proportionality, the slope $\beta$ and $90 \%$ confidence intervals (CIs) obtained from the power model as $\ln$ (AUC or $\left.\mathrm{C}_{\max }\right)=\alpha+\beta \times \ln ($ dose $)$ were computed by covariance (ANCOVA). The regression coefficient was significant at level 0.1 . The pre-defined criterion was set as $(0.500$, 2.000) (Hummel et al., 2009), and the criterion interval resulted in the value of $(0.3691,1.631)$. The differences in pharmacokinetic parameters among dose groups were compared using the analysis of variance (ANOVA), except for $\mathrm{t}_{\max }$, for which the non-parametric test (NPT) was used. Statistical comparisons between pharmacokinetic parameters of single and multiple doses were performed by the paired $t$-test (PTT). The differences in $\mathrm{C}_{\text {min }}$ on days 6,7 and 8 were compared using ANOVA to determine whether the steady state was reached in the multiple-dose study.

\section{Safety and tolerability assessment}

AEs, physical examinations, clinical laboratory 
tests, 12-lead ECGs and vital signs were monitored for safety and tolerability assessment. The relationship of AEs to the study drugs were graded as not related, probably not related, possibly related, probably related or definitely related. All adverse events were coded using the Medical Dictionary for Regulatory Activities $\left(\mathrm{MedDRA}^{\circledR}\right)$.

\section{RESULTS}

\section{Subjects}

A total of 52 subjects were enrolled in this study (40 in the SAD study and 12 in the MD study). All subjects completed this study. Table I summarizes the demographics of subjects. In general, subjects in different treatment groups were comparable in age, weight, BMI and metabolic measurements.

\section{Pharmacokinetic assessment}

The mean plasma concentration-time profiles of L-NBP following single-dose administration are shown in Figure 1; the pharmacokinetic parameters are presented in Table II. The results indicate that L-NBP was absorbed rapidly, with a median $\mathrm{t}_{\max }$ of $1 \mathrm{~h}, 1 \mathrm{~h}$ and $1.5 \mathrm{~h}$ across the study doses. The mean $\mathrm{t}_{1 / 2}$ of L-NBP was similar across all doses, ranging from 11.87 to $14.79 \mathrm{~h}$. Over the dose range of 160 to $482 \mathrm{mg}$, the mean $\mathrm{C}_{\max }$ increased from 241 to $1008 \mu \mathrm{g} / \mathrm{L}, \mathrm{AUC}_{0-\mathrm{t}}$ increased from 569.5 to $2711.9 \mathrm{~h} \cdot \mu \mathrm{g} / \mathrm{L}$, and $\mathrm{AUC}_{0-\infty}$ increased from 594.5 to $2827.4 \mathrm{~h} \cdot \mu \mathrm{g} / \mathrm{L}$. The predefined range for dose proportionality was $(0.3691$, 1.631). However, the mean slopes ( $90 \%$ CIs) were 1.420 $(0.946,1.894)$ for $\mathrm{C}_{\max }, 1.498(1.053,1.942)$ for $\mathrm{AUC}_{0-\mathrm{t}}$, and $1.478(1.042,1.915)$ for $\mathrm{AUC}_{0-\infty}$. The $90 \% \mathrm{CIs}$ for the ratio of dose-normalized of $\mathrm{C}_{\max }$ and AUC indicated that there was no apparent dose-proportionality over the range of 160 to $480 \mathrm{mg}$. The values of $t_{\max }$ and $t_{1 / 2}$ were doseindependent $(\mathrm{P}>0.05)$.

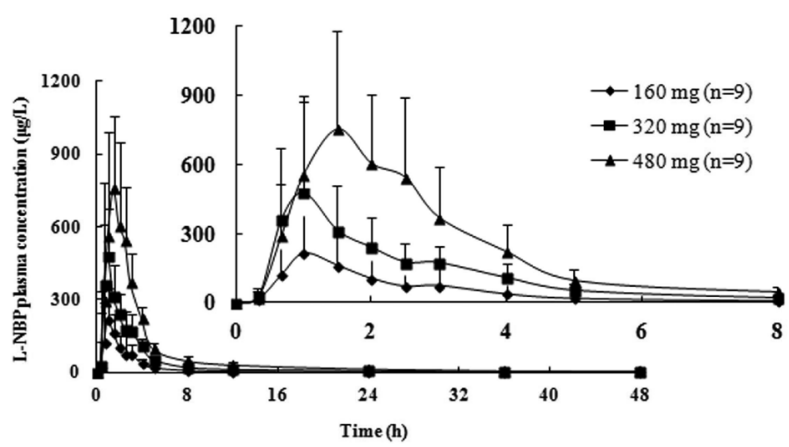

FIGURE 1 - Mean plasma concentration-time curves following administration of a single oral dose of L-NBP tablet at 160, 320, or $480 \mathrm{mg}$ in healthy Chinese subjects. Data are represented as mean \pm standard error of the mean.

The mean plasma concentration-time profiles of L-NBP after the first dose on day 1 and the last dose on day 9 are presented in Figure 2; the pharmacokinetic parameters from the non-compartmental analysis of measured plasma concentrations on day 1 and day 9 are presented in Table III. No significant difference in $\mathrm{C}_{\text {minss }}$ was found by ANOVA analysis, indicating that the steady state conditions were reached within 3 days after twice daily dosing. Under steady state conditions, L-NBP was rapidly absorbed with a median $\mathrm{t}_{\max }$ of $1.50 \mathrm{~h}$ and a mean $\mathrm{C}_{\max }$ of $217 \mu \mathrm{g} / \mathrm{L}$, which was identical to the single-dose parameters on day 1 . The $t_{\max }$ showed no significant difference between the first and the last dose. The $t_{1 / 2}$ showed significant difference between the first and the

TABLE I - Summary of demographic data

\begin{tabular}{|c|c|c|c|c|c|c|c|c|c|}
\hline \multirow{3}{*}{ Characteristic } & \multicolumn{7}{|c|}{ Single ascending dose } & \multicolumn{2}{|c|}{ Multiple dose } \\
\hline & L-NBP & L-NBP & \multirow[b]{2}{*}{ placebo } & L-NBP & \multirow[b]{2}{*}{ placebo } & L-NBP & \multirow[b]{2}{*}{ placebo } & L-NBP & \multirow[b]{2}{*}{ placebo } \\
\hline & $80 \mathrm{mg}$ & $160 \mathrm{mg}$ & & $320 \mathrm{mg}$ & & $480 \mathrm{mg}$ & & $\begin{array}{l}160 \mathrm{mg} \text { twice } \\
\text { daily for } 7 \mathrm{~d}\end{array}$ & \\
\hline $\mathrm{n}$ & 4 & 9 & 3 & 9 & 3 & 9 & 3 & 10 & 2 \\
\hline \multicolumn{10}{|l|}{ Gender } \\
\hline male & 2 & 5 & 1 & 4 & 2 & 4 & 2 & 5 & 1 \\
\hline female & 2 & 4 & 2 & 5 & 1 & 5 & 1 & 5 & 1 \\
\hline Age (y) & $22 \pm 1$ & $23 \pm 2$ & $24 \pm 2$ & $23 \pm 2$ & $25 \pm 3$ & $23 \pm 2$ & $21 \pm 1$ & $23 \pm 3$ & $21 \pm 0$ \\
\hline Bodyweight (kg) & $61.4 \pm 9.8$ & $59.5 \pm 9.2$ & $59.7 \pm 5.5$ & $58.7 \pm 7.1$ & $63.7 \pm 9.3$ & $56.5 \pm 5.0$ & $58.5 \pm 7.6$ & $56.1 \pm 6.4$ & $52.3 \pm 3.2$ \\
\hline Height $(\mathrm{cm})$ & $167.5 \pm 6.6$ & $166.9 \pm 11.2$ & $165.3 \pm 6.4$ & $165.6 \pm 7.9$ & $170.0 \pm 14.0$ & $164.5 \pm 7.2$ & $168.3 \pm 13.5$ & $165.1 \pm 7.7$ & $161.0 \pm 11.3$ \\
\hline BMI $\left(\mathrm{kg} / \mathrm{m}^{2}\right)$ & $21.8 \pm 2.0$ & $21.2 \pm 1.2$ & $21.8 \pm 0.7$ & $21.4 \pm 1.3$ & $22.2 \pm 1.0$ & $20.9 \pm 1.5$ & $20.6 \pm 1.1$ & $20.6 \pm 1.2$ & $20.3 \pm 1.6$ \\
\hline
\end{tabular}

Data are mean \pm SD unless stated otherwise. $\mathrm{BMI}=$ body mass index; $\mathrm{SD}=$ standard deviation. 
TABLE II - Main pharmacokinetic parameters of L-NBP after single oral dose

\begin{tabular}{lccc}
\hline Parameter & $160 \mathrm{mg}(\mathrm{n}=9)$ & $320 \mathrm{mg}(\mathrm{n}=9)$ & $480 \mathrm{mg}(\mathrm{n}=9)$ \\
\hline $\mathrm{C}_{\max }(\mu \mathrm{g} / \mathrm{L})$ & $241 \pm 154$ & $557 \pm 354$ & $1008 \pm 265$ \\
$\mathrm{t}_{\max }(\mathrm{h})$ & $1.00(0.67-3.00)$ & $1.00(0.67-3.00)$ & $1.50(1.00-2.50)$ \\
$\mathrm{AUC}_{0-\mathrm{t}}(\mathrm{h} \cdot \mu \mathrm{g} / \mathrm{L})$ & $569.5 \pm 364.9$ & $1392.5 \pm 574.4$ & $2711.9 \pm 997.0$ \\
$\mathrm{AUC}_{0-\infty}(\mathrm{h} \cdot \mu \mathrm{g} / \mathrm{L})$ & $594.5 \pm 365.9$ & $1452.0 \pm 597.9$ & $2827.4 \pm 1062.6$ \\
$\mathrm{t}_{1 / 2}(\mathrm{~h})$ & $11.87 \pm 3.28$ & $14.79 \pm 2.93$ & $14.61 \pm 3.24$ \\
$\mathrm{Cl} / \mathrm{F}(\mathrm{L} / \mathrm{h})$ & $364.2 \pm 181.6$ & $259.2 \pm 112.2$ & $209.3 \pm 125.0$ \\
$\mathrm{Vz} / \mathrm{F}(\mathrm{L})$ & $6421.6 \pm 3826.2$ & $5680.5 \pm 3302.3$ & $4547.9 \pm 3671.6$ \\
\hline
\end{tabular}

Pharmacokinetic data are presented as mean $\pm \mathrm{SD}$, except for $\mathrm{t}_{\max }$, which is shown as median (range).

last dose. The mean AUC values were slightly higher in multiple-dosing regimen than the corresponding values obtained after single-dose administration on day 1 , and slight accumulation was found following multiple dosing of L-NBP tablets.

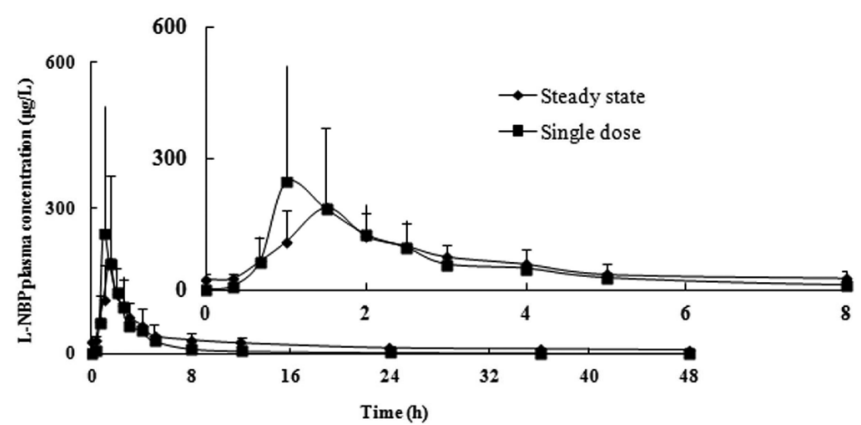

FIGURE 2 - Plasma concentration-time curves following a single dose or multiple doses (steady state) of L-NBP tablet $160 \mathrm{mg}$ twice daily for 7 days. Data are presented as mean \pm standard error of the mean.

\section{Safety and tolerability assessment}

A total of 23 subjects (14 in the SAD study and 9 in the MD study) among the 52 volunteers who received the drug investigational product (study drug or placebo) experienced AEs. In the SAD study, there were 25 AEs; 23 in the study drug group and 2 in the placebo group, respectively. Among them, somnolence $(n=2,480 \mathrm{mg})$ occurred in the study drug group and was assessed to be possibly related to the study drug. In the MD study, there were 25AEs; 19 in the study drug group and 6 in the placebo group, respectively. Among them, somnolence $(n=2)$, headache $(n=1)$, slowness to respond $(n=1)$, and nausea $(n=1)$ occurred in the study drug group and were assessed to be possibly related to the study drug. All reported AEs were mild or moderate in intensity and there were no SAEs, deaths or withdrawals.
TABLE III - Main pharmacokinetic parameters of L-NBP after multiple oral doses of $160 \mathrm{mg}$, with single dose on d 1, no treatment on $\mathrm{d} 2$ and successive dosing twice daily from $\mathrm{d} 3$ to $\mathrm{d} 9$

\begin{tabular}{lcc}
\hline Parameter & $\begin{array}{c}\text { single dose } \\
(\mathrm{d} 1)\end{array}$ & $\begin{array}{c}\text { multiple dose } \\
(\mathrm{d} 9)\end{array}$ \\
\hline $\mathrm{C}_{\max }(\mu \mathrm{g} / \mathrm{L})$ & $266 \pm 233$ & $217 \pm 165$ \\
$\mathrm{t}_{\text {max }}(\mathrm{h})$ & $1.25(1.00-4.00)$ & $1.50(1.00-4.00)$ \\
$\mathrm{AUC}_{0-\mathrm{t}}(\mathrm{h} \cdot \mu \mathrm{g} / \mathrm{L})$ & $563.4 \pm 320.1$ & $1022.4 \pm 337.7$ \\
$\mathrm{AUC}_{0-\infty}(\mathrm{h} \cdot \mu \mathrm{g} / \mathrm{L})$ & $585.7 \pm 320.0$ & $1245.2 \pm 382.3$ \\
$\mathrm{t}_{1 / 2}(\mathrm{~h})$ & $12.35 \pm 5.91$ & $22.73 \pm 8.61$ \\
$\mathrm{Vz} / \mathrm{F}(\mathrm{L})$ & $5601.3 \pm 3161.3$ & $10011.03 \pm 5793.07$ \\
$\mathrm{Cl} / \mathrm{F}(\mathrm{L} / \mathrm{h})$ & $330.1 \pm 129.7$ & $290.7 \pm 105.0$ \\
$\mathrm{C}_{\text {avg }}(\mu \mathrm{g} / \mathrm{L})$ & & $51.5 \pm 18.3$ \\
$\mathrm{AUC}$ & & $617.4 \pm 220.2$ \\
$\mathrm{DF}$ & & 3.70 \\
$\mathrm{R}_{\text {cmax }}$ & & 0.82 \\
$\mathrm{R}_{\mathrm{AUC}}$ & & 1.45 \\
\hline
\end{tabular}

Pharmacokinetic data are presented as mean $\pm \mathrm{SD}$, except for $\mathrm{t}_{\max }$, which is shown as median (range).

There were no significant clinical findings in the hematology tests, blood chemistry examinations, urine tests or ECGs in the safety assessment of the study subjects during the study periods, and all results were within normal ranges. Vital signs, including the blood pressure, pulse rate and body temperature, and the physical examination results of the SAD and MD study participants showed no clinically significant changes.

L-NBP tablet was safe and well tolerated when administered as single-dose at up to $480 \mathrm{mg}$ and multipledose at $160 \mathrm{mg}$, twice daily for 7 days. All subjects were in good compliance. 


\section{DISCUSSION}

The current study characterizes the pharmacokinetic, safety and tolerability profiles of L-NBP tablets in healthy Chinese volunteers undergoing either single or twicedaily dosing regimens. The doses selected were based on findings from the preclinical studies and the phase I study of the DL-NBP soft capsule, carried out at the Peking Union Medical College Hospital in 2004. L-NBP was absorbed rapidly after administration of a single-dose, with $\mathrm{C}_{\max }$ reached within approximately $1 \mathrm{~h}$. The steady-state conditions were achieved within 3 days after twice daily dosing of the $160 \mathrm{mg}$ L-NBP tablet.

The main AEs of the listed DL-NBP soft capsule are moderately elevated aminotransferase, nausea, abdominal discomfort, skin rashes and mental symptoms. In the current study, the AEs of the L-NBP tablet occurred less frequently and were and milder than those listed for the DL-NBP soft capsule. Somnolence, headache, slowness to respond, and nausea were assessed to be possibly related to the study drug. Among them, somnolence occurred in the high single-dose group (480 mg), and the other AEs occurred after multiple dosing.

In the SAD study, both $\mathrm{C}_{\text {max }}$ and AUC increased with dose escalation, but dose proportionality was not observed over the range of 160 to $480 \mathrm{mg}$. The values of $\mathrm{t}_{\max }$ and $t_{1 / 2}$ were dose-independent. The mean $t_{1 / 2}$ of L-NBP was similar across all doses. The $t_{\max }$ of the L-NBP tablet was similar, but the $t_{1 / 2}$ of the L-NBP tablet was longer, when compared to the listed DL-NBP soft capsule.

In the MD study, there was no difference in $\mathrm{C}_{\text {min-ss, }}$ as detected by ANOVA analysis. The $t_{\max }$ showed no significant difference between the first and the last dose. The steady-state was reached within 3 days after twice daily dosing with the $160 \mathrm{mg}$ L-NBP tablet. The mean $\mathrm{AUC}_{0-\mathrm{t}}$ was slightly higher after multiple-dose administration $(1022.4 \pm 337.7 \mathrm{~h} \cdot \mu \mathrm{g} / \mathrm{L})$ than that obtained after single-dose administration $(563.4 \pm 320.1 \mathrm{~h} \cdot \mu \mathrm{g} / \mathrm{L})$, and the $\mathrm{R}_{\mathrm{AUC}}$ of 1.45 was for $\mathrm{AUC}_{0-\tau}(\tau=12 \mathrm{~h})$. The $\mathrm{t}_{1 / 2}$ was longer after multiple-dose administration $(22.73 \pm 8.61 \mathrm{~h})$ than that obtained after single-dose administration (12.35 $\pm 5.91 \mathrm{~h}$ ), and showed significant differences. Therefore, slight accumulation was found after multiple doses. The pharmacokinetic behavior of the $160 \mathrm{mg}$ L-NBP tablet administered twice daily for 7 days was similar to that of the $200 \mathrm{mg}$ DL-NBP soft capsule administered every 6 hours for 7 days. The pharmacokinetic parameters for the DL- NBP soft capsule were provided by the Zhongqi Pharmacy of CSPC Pharma. (Shijiazhuang, China).

All AEs were mild, of limited duration. There were no SAEs, death or withdrawal. However, it is necessary to evaluate the effect of long-term doses of the L-NBP tablet on the nervous system, cardiovascular system, ECG and vision in the future studies.

\section{CONCLUSIONS}

The present study demonstrated the safety, tolerability and pharmacokinetics of the L-NBP tablet after single or multiple doses in healthy Chinese subjects. L-NBP was absorbed rapidly, and both the $\mathrm{C}_{\max }$ and the AUC increased with dose escalation; dose proportionality was not observed over the range of $160 \mathrm{mg}$ to $480 \mathrm{mg}$. The steady state was achieved within 3 days after twice daily dosing with the $160 \mathrm{mg}$ L-NBP tablet. Slight accumulation was found after multiple doses. The L-NBP tablet was well tolerated in healthy Chinese volunteers over the studied dose range.

\section{ACKNOWLEDGEMENT}

The study was supported by the Zhongqi Pharmacy of CSPC Pharma. (Shijiazhuang, China). The authors thank all of the subjects enrolled in this study. We also thank the staff of the clinical ward and bioanalytical lab of the clinical pharmacology laboratory in the Second Affiliated Hospital of Soochow University (Suzhou, China).

The authors have no conflicts of interest that are directly relevant to the content of this study.

The authors acknowledge Dr. Michael Van Meter for the assistances in writing the manuscript.

\section{REFERENCES}

CHANG, Q.; WANG, X.L. Effects of chiral 3-n-butylphthalide on apoptosis induced by transient focal cerebral ischemia in rats. Acta Pharmacol. Sin., v.24, n.8, p.796-804, 2003.

HUAI, Y.; DONG, Y.; XU, J.; MENG, N.; SOMG, C.; LI, W.; LV, P. L-3-n-butylphthalide protects against vascular dementia via activation of the Akt kinase pathway. Neural. Regen. Res., v.8, n.19, p.1733-1742, 2013.

HUMMEL, J.; MCKENDRICK, S.; BRINDLEY, C.; FRENCH, R. Exploratory assessment of dose proportionality: review of current approaches and proposal for a practical criterion. Pharm. Stat., v.8, n.1, p.38-49, 2009. 
PENG, Y.; SUN, J.; HON, S.; NYLANDER, A.N.; XIA, W.; FENG, Y.; WANG, X.; LEMERE, C.A. L-3-nbutylphthalide improves cognitive impairment and reduces amyloid- $\beta$ in a transgenic model of Alzheimer's disease. $J$. Neurosci., v.30, n.24, p.8180-8189, 2010.

PENG, Y.; XING, C.; XU, S.; LEMERE, C.A.; CHEN, G.; LIU, B.; WANG, L.; FENG, Y.; WANG, X. L-3-nbutylphthalide improves cognitive impairment induced by intracerebroventricular infusion of amyloid- $\beta$ peptide in rats. Eur. J. Pharmacol., v.621, n.1-3, p.38-45, 2009.

PENG, Y.; HU, Y.; XU, S.; LI, P.; LI, J.; LU, L.; YANG, H.; FENG, N.; WANG, L.; WANG, X. L-3-n-butylphthalide reduces tau phosphorylation and improves cognitive deficits in A $\beta \mathrm{PP} / \mathrm{PS} 1-A l z h e i m e r$ 's transgenic mice. J. Alzheimer's Dis., v.29, n.2, p.379-391, 2012.

PENG, Y.; XING, C.; LEMERE, C.A.; CHEN, G.; WANG, L.; FENG, Y.; WANG, X. 1-3-n-butylphthalide ameliorates beta-amyloid-induced neuronal toxicity in cultured neuronal cells. Neurosci. Lett., v.434, n.2, p.224-229, 2008.
SHI, A.; HUA, W.; ZHANG, Q. Determination of L-Butylphthalide in human plasma by LC-MS/MS. Chin. Hosp. Pharm. J., v.30, n.4, p.349-352, 2010.

XIANG, J.; PAN, J.; CHEN, F.; ZHENG, L.; CHEN, Y.; ZHANG, S.; FENG, W. L-3-n-butylphthalide improves cognitive impairment of APP/PS1 mice by BDNF/TrkB/ PI3K/AKT pathway. Int. J. Clin. Exp. Med., v.7, n.7, p.17061713,2014

WANG, M.; ZHANG, Q.; PAN, J.; SHI, A.; HUA, W.; ZHU, Y.; XU, H.; MENG, Z. Safety, tolerability and pharmacokinetics of L-3-N-Butylphthalide sodium chloride injection in healthy Chinese subjects. Lat. Am. J. Pharm., v.33, n.10, p.1637-1643, 2014.

Received for publication on $05^{\text {th }}$ January 2015 Accepted for publication on $11^{\text {th }}$ June 2015 
